\title{
Corrigendum: Three Flute Players' Lived Experiences of Dalcroze Eurhythmics in Preparing Contemporary Music for Performance
}

OPEN ACCESS

Approved by: Frontiers Editorial Office, Frontiers Media SA, Switzerland

${ }^{*}$ Correspondence: Rosalind Ridout rosalindridout@gmail.com

Specialty section: This article was submitted to Educational Psychology,

a section of the journal

Frontiers in Education

Received: 05 May 2020 Accepted: 06 May 2020

Published: 02 June 2020

Citation:

Ridout $R$ and Habron J (2020)

Corrigendum: Three Flute Players

Lived Experiences of Dalcroze

Eurhythmics in Preparing Contemporary Music for Performance.

Front. Educ. 5:70

doi: 10.3389/feduc.2020.00070

\section{Rosalind Ridout ${ }^{1 *}$ and John Habron ${ }^{2,3}$}

${ }^{1}$ The Jack \& Jill Family of Schools, London, United Kingdom, ${ }^{2}$ Royal Northern College of Music, Manchester, United Kingdom, ${ }^{3}$ MASARA, North-West University, Potchefstroom, South Africa

Keywords: Dalcroze Eurhythmics, flute, rehearsal, performance, lived experience, interpretative phenomenological analysis (IPA)

\section{A Corrigendum on}

Three Flute Players' Lived Experiences of Dalcroze Eurhythmics in Preparing Contemporary Music for Performance

by Ridout, R., and Habron, J. (2020). Front. Educ. 5:18. doi: 10.3389/feduc.2020.00018

In the published article, there was an error regarding the affiliations for John Habron. As well as having affiliation 2 he should also have "MASARA, North-West University, Potchefstroom, South Africa."

The authors apologize for this error and state that this does not change the scientific conclusions of the article in any way. The original article has been updated.

Copyright $\odot 2020$ Ridout and Habron. This is an open-access article distributed under the terms of the Creative Commons Attribution License (CC BY). The use, distribution or reproduction in other forums is permitted, provided the original author(s) and the copyright owner(s) are credited and that the original publication in this journal is cited, in accordance with accepted academic practice. No use, distribution or reproduction is permitted which does not comply with these terms. 